\title{
CHANGES IN THE UPPER URINARY TRACT AS DEMONSTRATED ON INTRAVENOUS PYELOGRAPHY AND MICTURATING CYSTO- URETHROGRAPHY IN PATIENTS WITH SPINAL CORD INJURY
}

\author{
By A. T. SCHER, M.B.Ch.B., D.M.R.D. \\ Spinal Injuries Centre, Conradie Hospital, Cape Town, South Africa
}

DECREASED renal function is well recognised as being an important cause of death in patients with spinal cord injuries and post-mortem examination of patients with spinal cord injury frequently shows evidence of renal damage (Comarr, 196I).

The radiological findings on intravenous pyelography and micturating cystourethrography in Ioo patients with spinal cord injury (i.e. paraplegia or tetraplegia) were analysed. In all the patients both examinations were performed within several days of each other.

Particular attention was paid to the following radiological features:

a. Hydronephrosis.

b. Chronic pyelonephritis.

c. Correlation between vesico-ureteric reflux on M.C.U.G. and abnormal I.V.P. findings.

\section{TECHNIQUE OF EXAMINATION}

Intravenous pyelography. I0o ml. of Urografin 60 per cent was administered by infusion in all patients. Films were obtained routinely at five, ten, and fifteen minutes and delayed films were obtained where necessary.

Micturating Cysto-urethrography. The bladder is filled with contrast material using a Foley's catheter and glass funnel. The funnel is held at a height of $15 \mathrm{~cm}$. and an X-ray film is exposed, the funnel is then raised to a height of $30 \mathrm{~cm}$., and a second X-ray obtained. The patient is placed in a steeply oblique position, the catheter is removed and a micturating film is then obtained. At the conclusion of the examination a post-micturition film is also obtained.

\section{RESULTS}

Hydronephrosis. Dilatation of the calyces and renal pelvis were divided into two groups, i.e. slight to moderate dilatation and gross dilatation. Measurement of the thickness of the renal parenchyma as performed by (Najenson et al., 1969) was not done, since it is our experience that most patients with spinal cord injury had a partial ileus and despite thorough bowel preparation detail of the renal outlines is frequently obscured by faecal and gas shadows. It would appear that tomography is essential for adequate evaluation of the renal outlines in these patients, but this has not been done due to lack of facilities. 
TABLE I

Level of lesion (hydronephrosis)

\begin{tabular}{|c|c|c|c|}
\hline & No dilatation & Hydronephrosis & Total \\
\hline Tetraplegia & $28(84.5 \%)$ & $6(17.5 \%)$ & 34 \\
\hline Paraplegia & $52(78 \%)$ & I4 (22\%) & 66 \\
\hline Total & 80 & 20 & 100 \\
\hline
\end{tabular}

TABLE II

Type of paralysis (hydronephrosis)

\begin{tabular}{|c|c|c|c|}
\hline & No dilatation & Hydronephrosis & Total \\
\hline $\begin{array}{c}\text { Complete } \\
\text { Incomplete }\end{array}$ & $\begin{array}{c}49(77.5 \%) \\
31(84 \%)\end{array}$ & $\begin{array}{c}\text { I4 (22.5\%) } \\
6(16 \%)\end{array}$ & 63 \\
\hline Total & 80 & 20 & 37 \\
\hline
\end{tabular}

Hydronephrosis was found in 20 per cent of the patients examined, in 12 cases being bilateral and in eight cases unilateral. Tables I, II and II demonstrate the relationship between the hydronephrosis and the level of paralysis, degree of paralysis and duration of paralysis. Analysis of the results has not revealed any significant relationship between the level of paralysis and the incidence of hydronephrosis which is in keeping with the findings of (Ascoli, 1970) and (Najenson et al., I969). There is a slightly higher incidence in cases of complete paralysis. The overall incidence of 20 per cent is exactly the same as that found by Ascoli. Of interest is the finding that seven out of the eight cases of unilateral hydronephrosis involved the right kidney.

Chronic Pyelonephritis. Chronic pyelonephritis as evidenced by scarring of the renal outlines and dilatation and deformity of the calyces was present in 12 ( 12 per cent) of patients. In nine cases only one side was involved and in three cases there was bilateral disease. The distribution of cases is shown in Tables IV, $\mathrm{V}$ and VI.

Analysis of the incidence of chronic pyelonephritis reveals a higher incidence in complete paralysis rather than in incomplete lesions as found by (Najenson et al., I969) and also a higher incidence in paraplegics as compared with tetraplegics.

Of interest is the finding that there is no greater incidence in patients who have been paralysed for more than four years as one would tend to expect.

Of the nine cases of unilateral chronic pyelonephritis in only one case was the left kidney involved, the other eight cases all showing right kidney involvement.

Vesico-ureteric Reflux. V.U. reflux was found in I3 ( 13 per cent) of cases, with bilateral reflux being present in four cases and unilateral reflux being present 
TABLE III

Years after trauma

\begin{tabular}{|c|c|c|c|}
\hline & No dilatation & Hydronephrosis & Total \\
\hline Four years or more & $23(76.5 \%)$ & $7(13.5 \%)$ & 30 \\
Less than four years & $57(8 \mathrm{r} \cdot 5 \%)$ & $13(\mathrm{I} 8.5 \%)$ & 70 \\
\hline Total & 80 & 20 & 100 \\
\hline
\end{tabular}

TABLE IV

Level of lesion (chronic pyelonephritis)

\begin{tabular}{|c|c|c|c|}
\hline & No changes & $\begin{array}{c}\text { Chronic } \\
\text { pyelonephritis }\end{array}$ & Total \\
\hline $\begin{array}{l}\text { Tetraplegia } \\
\text { Paraplegia }\end{array}$ & $32(94 \%)$ & $2(6 \%)$ & 34 \\
\hline Total & 88 & I0 $(15 \%)$ & 66 \\
\hline
\end{tabular}

TABLE V

Type of paralysis (chronic pyelonephritis)

\begin{tabular}{|c|c|c|c|}
\hline & No changes & $\begin{array}{c}\text { Chronic } \\
\text { pyelonephritis }\end{array}$ & Total \\
\hline Complete & $53(84 \%)$ & I0 $(16 \%)$ & 63 \\
Incomplete & $35(95 \%)$ & $2(5 \%)$ & 37 \\
\hline Total & 88 & I2 & I00 \\
\hline
\end{tabular}

\section{TABLE VI}

Years after trauma (chronic pyelonephritis)

\begin{tabular}{|c|c|c|c|}
\hline & No changes & $\begin{array}{c}\text { Chronic } \\
\text { pyelonephritis }\end{array}$ & Total \\
\hline Four years or more & $27(90 \%)$ & $3(10 \%)$ & 30 \\
\hline Less than four years & $61(87 \%)$ & $9(13 \%)$ & 70 \\
\hline Total & 88 & I & 100 \\
\hline
\end{tabular}

I3/3-C 
TABLE VII

Levels of lesion (V.U. reflux)

\begin{tabular}{|c|c|c|c|} 
& No reflux & Reflux & Total \\
\hline $\begin{array}{c}\text { Tetraplegia } \\
\text { Paraplegia }\end{array}$ & $25(74 \%)$ & $9(26 \%)$ & 34 \\
\hline Total & 87 & $4(6 \%)$ & 66 \\
\hline & $87 \%$ & 13 & I00 \\
\hline
\end{tabular}

TABLE VIII

Type of paralysis (V.U. reflux)

\begin{tabular}{|l|c|c|c|}
\hline & No reflux & Reflux & Total \\
\hline Complete & $53(84 \%)$ & IO $(16 \%)$ & 63 \\
Incomplete & $34(92 \%)$ & $3(8 \%)$ & 37 \\
\hline Total & 87 & I3 & 100 \\
\hline
\end{tabular}

TABLE IX

\begin{tabular}{|l|c|c|c|}
\hline & No reflux & Reflux & Total \\
\hline Four years or more & $18(78 \%)$ & $5(22 \%)$ & 23 \\
\hline Less than four years & $69(90 \%)$ & $8(10 \%)$ & 77 \\
\hline Total & 87 & 13 & 100 \\
\hline
\end{tabular}

in the remaining nine cases. Of the 13 cases, six showed no evidence of any abnormality on I.V.P. Six had evidence of chronic pyelonephritis on I.V.P. and one showed evidence of hydronephrosis. The distribution of cases is shown in Tables VII, VIII and IX.

Of interest is the higher incidence of V.U. reflux in tetraplegics and in patients who had been paralysed for more than four years. Of particular interest was the markedly higher incidence in complete lesions.

Approximately 50 per cent of cases with V.U. reflux showed radiological evidence of chronic pyelonephritis whereas the overall incidence of chronic pyelonephritis in the IOO cases examined was only I2 per cent.

The incidence of V.U. reflux observed may have been higher had these examinations been performed with cine or videotape monitoring since it is well known that V.U. reflux is often radiologically transient.

Cobb (1966) has stated that seeing the ureters along their full length on I.V.P. is of help in the diagnosis of V.U. reflux, but virtually all our cases showed visualisation of the entire course of the ureter probably due to the large dose of contrast administered. 


\section{SUMMARY}

I. Thirty-two per cent of cases examined by I.V.P. showed evidence of disease (20 per cent hydronephrosis, I2 per cent chronic pyelonephritis).

2. The incidence of V.U. reflux on micturating cysto-urethrography was I 3 per cent. V.U. reflux is associated with chronic pyelonephritis in a high proportion of cases as would be expected. A normal pyelogram does not exclude V.U. reflux as mentioned by Cobb (1966).

3. Patients with complete paralysis show a significantly high incidence of chronic pyelonephritis, hydronephritis and V.U. reflux.

4. In case of unilateral hydronephrosis and chronic pyelonephritis there is a striking predilection for involvement of the right kidney. The cause for this is not evident but possibly the fact that the right ureter is shorter than the left is a factor.

\section{RÉSUMÉ}

I. Trente-deux pour cent des cas examinés par I.V.P. donnaient des signes de maladie (20 pour cent d'hydronéphrose, I2 pour cent de pyélonéphrite chronique).

2. L'incidence du reflux de V.U. sur la cysto-uréthrographie en miction était de I3 pour cent. Le reflux de V.U. est associé à la pyélonéphrite chronique dans une grande partie des cas comme on s'y attend. Un pyélogramme normal n'exclut pas le reflux de V.U. comme mentionné par Cobb I966.

3. Les malades atteints de paralysie complète montrent une incidence très élevée de la pyélonéphrite chronique de l'hydronéphrite et du reflux de V.U.

4. Dans les cas d'hydronéphrose unilatérale et de pyélonéphrite chronique, on constate une prédilection frappante pour l'engagement du rein droit. La cause de ce phénomène n'est pas évidente mais un facteur possible est le fait que l'uretère froit est plus court que le gauche.

\section{ZUSAMMENFASSUNG}

I. 32 per cent der Fälle zeigten 20 Prozent Hydronephrosis und I2 Prozent chronische Pyeolnephritis im I.V.P.

2. Dreizehn Prozent zeigten Reflux bei Cysto-Urethrographie. Ein normales Pyelogramm schliesst Reflux nicht aus.

3. Patienten mit kompletten Läsionen haben einen hohen Prozentsatz von chronischer Pyelonephritis, Hydronephrose und Reflux.

4. Die rechte Niere ist zeigte eine besondere Predilektion für diese Pathologien. Ein möglicher Grund hierfür könnte die Tatsache sein, dass der rechte Ureter kürzer als der linke ist.

Acknowledgements. Thanks are due to Dr. D. F. Smith, Medical Superintendent for permission to publish this article, to Dr. A. Key, Head of the Spinal Injuries Unit for her assistance and to Mrs. L. Fraenkel for the typing and preparation.

\section{REFERENCES}

Ascoli \& Franch (1970). Dilatation of the upper urinary tract in paraplegics. Int. $\mathcal{f}$ Paraplegia, 8, I96.

СовB \& TALBOT (1966). Radiological findings in early vesico-ureteric reflux among spinal cord injury patients. Int. F. Paraplegia, 4, 243.

COMARR (I96I). Chronic infection of the urinary tract among patients with spinal cord injuries. F. Urol. 85, 983-987.

NAJENSON et al. (I969). Upper urinary tract in patients after traumatic spinal cord injury. Int. F. Paraplegia, 7, 85 . 